Recommended by Doctor of Pharmacy, Professor A. M. Komissarenko

UDC 547.47:581.43:582.711.712

DOI: $10.24959 /$ nphj. 17.2150

T. V. Oproshanska, O. P. Khvorost, L. V. Ocheredko

National University of Pharmacy

\title{
Determination of the quantitative content of the amount of organic acids and ascorbic acid in different batches of Rosa majalis and Rosa canina raw material
}

Rose hips are the pharmacopoeial raw material, and its roots have been widely used in folk medicine. Therefore, these roots attracted our attention. The chemical composition of roots of both Rosa species has been poorly studied. The data of literature sources show that roots contain phenolic compounds, organic acids and amino acids. Rose hips are standardized by the quantitative content of the amount of organic acids and ascorbic acid according to the State Pharmacopoeia of the USSR of the XI-th edition. According to the State Pharmacopoeia of Ukraine (SPhU) 2.0 this raw material is standardized by the quantitative content of ascorbic acid.

Aim. To study the quantitative content of the amount of organic acids and ascorbic acid in different batches of samples of Rosa majalis and Rosa canina roots.

Material and methods. Roots of Rosa majalis and Rosa canina collected in different regions of Ukraine during 2014-2016 were used for research. The quantitative content of the amount of organic acids was studied by the titration method. Ascorbic acid was determined by the spectrophotometric method.

Results and discussion. As a result of studying the quantitative content of the amount of organic acids it was determined that the content of these substances in the raw material ranged from $3 \%$ to $5 \%$ in the roots of Rosa majalis and from $3 \%$ to $4.5 \%$ in the roots of Rosa canina. The content of ascorbic acid in roots of Rosa majalis and Rosa canina fluctuated insignificantly from $0.11 \%$ to $0.13 \%$.

Conclusions. For the first time the quantitative content of the amount of organic acids and ascorbic acid in Rosa majalis and Rosa canina roots collected during three years in seven different places has been determined. The results of our research show that further studying of Rosa majalis and Rosa canina roots is promising taking into account their possible areas of application.

Key words: dog rose; root; organic acids; ascorbic acid

\section{Т. В. Опрошанська, О. П. Хворост, Л. В. Очередько}

Кількісне визначення суми органічних кислот та аскорбінової кислоти в різних серіях сировини шипшини травневої та шипшини собачої

Фармакопейною сировиною є плоди шипшини, а її корені використовуються в народній медицині, тому вони і привернули нашу увагу. Хімічний склад коренів вивчений мало. В літературі $є$ відомості про кількісний вміст різних груп фенольних сполук, органічних кислот, амінокислот. Згідно з ДФ СРСР XI видання плоди шипшини стандартизують за кількісним вмістом суми органічних кислот та аскорбінової кислоти. Згідно з ДФУ 2.0 цю сировину стандартизують за вмістом аскорбінової кислоти.

Мета роботи - визначення кількісного вмісту суми органічних кислот та аскорбінової кислоти в різних серіях коренів шипшини травневої та шипшини собачої.

Матеріали та методи. Для дослідження використовували корінь шипшини травневої та шипшини собачої, який заготовляли восени у різних областях України протягом 2014-2016 років. Кількісний вміст суми органічних кислот визначали титриметричним методом, а аскорбінової кислоти - методом спектрофотометрії.

Результати та їх обговорення. В результаті визначення кількісного вмісту суми органічних кислот у коренях шипшини травневої було встановлено, що вміст цих речовин у сировині коливався від 3 \% до 5 \%, тоді як у коренях шипшини собачої - від 3 \% до 4,5\%. Вміст аскорбінової кислоти в коренях коливався незначно від $0,11 \%$ до $0,13 \%$.

Висновки. Вперше визначено кількісний вміст суми органічних кислот та аскорбінової кислоти в коренях шипшини травневої та шипшини собачої протягом 3 років 37 місць заготівлі. Результати проведеного дослідження показали перспективність подальшого вивчення коренів шипшини травневої та шипшини собачої, зважаючи на можливі аспекти їх застосування.

Ключові слова: шипшина; корінь; органічні кислоти; аскорбінова кислота

Т. В. Опрошанская, О. П. Хворост, Л. В. Очередько

Количественное определение суммы органических кислот и аскорбиновой кислоты в разных сериях сырья шиповника майского и шиповника собачьего

Фармакопейным сырьем являются плоды шиповника, а его корни используются в народной медицине, поэтому они и привлекли наше внимание. Химический состав корней изучен мало. В литературе есть данные про количественное содержание разных групп фенольных соединений, органических кислот и аминокислот. Согласно ГФ СССР XI издания плоды шиповника стандартизуют по количественному содержанию суммы органических кислот и аскорбиновой кислоты. Согласно ГФУ 2.0 это сырье стандартизируют по содержанию аскорбиновой кислоты. 
Цель работы - изучение количественного содержания суммы органических кислот и аскорбиновой кислоты в разных сериях корней шиповника майского и шиповника собачьего.

Материалы и методы. Для исследования использовали корень шиповника майского и шиповника собачьего, который заготавливали осенью в разных областях Украины в течении 2014-2016 годов. Количественное содержание суммы органических кислот определяли титриметрическим методом, а аскорбиновой кислоты методом спектрофотометрии.

Результаты и их обсуждение. В результате определения количественного содержания суммы органических кислот в корнях шиповника майского было установлено, что содержание этих веществ в сырье колебалось от $3 \%$ до $5 \%$, тогда как в корнях шиповника собачьего - от 3 \% до 4,5\%. Содержание аскорбиновой кислоты в корнях колебалось незначительно от 0,11 \% до 0,13\%.

Выводы. Впервые определено количественное содержание суммы органических веществ и аскорбиновой кислоты в корнях шиповника майского и шиповника собачьего в течении 3 лет из 7 мест произрастания. Результаты проведенного исследования показали перспективность дальнейшего изучения корней шиповника майского и шиповника собачьего, учитывая возможные аспекты их применения.

Ключевые слова: шиповник; корень; органические кислоты; аскорбиновая кислота

Rose hips are the pharmacopoeial raw material [1,2]. The raw material of Rosaceae Family has been widely used in folk medicine. The roots of Rosa majalis and Rosa canina attracted our attention. They are widely used in folk medicine and have the anti-inflammatory, antibacterial, antioxidant, litholytic and choleretic activity, and normalize metabolic processes in the body $[3,4,5]$. The chemical composition of roots of both Rosa species has been poorly studied. The data of literature sources show that the roots of Rosa majalis contain organic acids, flavonoids and tannins. Previously, the component composition of organic acids and volatile substances in this raw material was also studied by us using chromatographymass spectrometry $[6,7]$. There is information about the quantitative content of the amount of free organic acids having the antimicrobic activity [8] in the roots of Rosa canina, as well as ascorbinic acid, which improves metabolism and appetite, increases vitality and takes part in forming hormones, tissue regeneration and blood coagulation. Moreover, this raw material contains polysaccharides, tannins, saponins and amino acids $[9,10]$.

Rose hips are standardized by the quantitative content of the amount of organic acids (not less than 2.6\%) and ascorbic acid (not less than $0.2 \%$ ) according to the State Pharmacopoeia of the USSR of the XI-th edition. According to the State Pharmacopoeia of Ukraine (SPhU)
2.0 this raw material is standardized by the quantitative content of ascorbic acid (not less than $0.3 \%$ ). Therefore, we decided to study the dynamics of accumulation of these groups of substances in underground organs of Rosa majalis and Rosa canina collected in different places and years.

The aim of our research was to study the quantitative content of the amount of organic acids and ascorbic acid in different batches of samples of Rosa majalis and Rosa canina roots.

\section{Materials and Methods}

Roots of Rosa majalis and Rosa canina collected in Kharkiv (batch 1), Chernovtsy (batch 2), Kyiv (batch 3), Vinnytsia (batch 4), Khmelnitskiy (batch 5), Ternopil (batch 6) and Ivano-Frankivsk (batch 7) regions during 2014-2016 were used for research. The quantitative content of the amount of organic acids was studied by the titration method according to the method of the State Pharmacopoeia of the USSR of the XI-th edition calculated with reference to malic acid (article No.38 "Rose Hips"). Ascorbic acid was determined by the spectrophotometric method according to the method of the SPhU 2.0 (monograph "Rosa") $[1,2]$.

\section{Results and Discussion}

The results of the research are given in Tab. 1 and 2. As a result of studying the quantitative content of the

Table 1

The results of quantitative determination of the amount of organic acids in different batches of Rosa majalis and Rosa canina roots $(\mathrm{m}=5(\%)$ calculated with reference to malic acid, calculated with reference to absolutely dry raw material)

\begin{tabular}{|c|c|c|c|c|c|c|c|}
\hline \multirow{2}{*}{ Year of collection } & \multicolumn{7}{|c|}{ The quantitative content in } \\
\cline { 2 - 7 } & batch 1 & batch 2 & batch 3 & batch 4 & batch 5 & batch 6 & batch 7 \\
\hline \multicolumn{8}{|c|}{ Rosa majalis } \\
\hline 2014 & $3.72 \pm 0.27$ & $4.02 \pm 0.27$ & $3.78 \pm 0.30$ & $4.33 \pm 0.27$ & $4.39 \pm 0.34$ & $3.68 \pm 0.26$ & $3.68 \pm 0.24$ \\
\hline 2015 & $3.75 \pm 0.23$ & $4.82 \pm 0.32$ & $4.53 \pm 0.30$ & $4.89 \pm 0.30$ & $5.07 \pm 0.31$ & $3.38 \pm 0.23$ & $3.64 \pm 0.25$ \\
\hline 2016 & $4.58+0.28$ & $3.69+0.25$ & $3.86+0.24$ & $4.47+0.28$ & $4.63+0.28$ & $4.74+0.30$ & $4.63+0.29$ \\
\hline \multicolumn{8}{|c|}{ Rosa canina } \\
\hline 2014 & $4.02 \pm 0.26$ & $3.62 \pm 0.23$ & $3.58 \pm 0.22$ & $3.58 \pm 0.23$ & $3.48 \pm 0.23$ & $3.29 \pm 0.22$ & $3.73 \pm 0.24$ \\
\hline 2015 & $3.65 \pm 0.25$ & $4.19 \pm 0.26$ & $4.33 \pm 0.26$ & $3.72 \pm 0.25$ & $4.26 \pm 0.28$ & $4.54 \pm 0.28$ & $4.29 \pm 0.24$ \\
\hline 2016 & $3.71+0.21$ & $3.52+0.21$ & $3.54+0.24$ & $4.08+0.25$ & $3.48+0.23$ & $4.15+0.25$ & $3.80+0.24$ \\
\hline
\end{tabular}


The results of quantitative determination of ascorbic acid in different batches of Rosa majalis and Rosa canina roots $(\mathrm{m}=5(\%)$ calculated with reference to ascorbic acid, calculated with reference to absolutely dry raw material)

\begin{tabular}{|c|c|c|c|c|c|c|c|}
\hline \multirow{2}{*}{ Year of collection } & \multicolumn{7}{c|}{ The quantitative content in } \\
\cline { 2 - 7 } & batch 1 & batch 2 & batch 3 & batch 4 & batch 5 & batch 6 & batch 7 \\
\hline \multicolumn{9}{|c|}{ Rosa majalis } \\
\hline 2014 & $0.12 \pm 0.01$ & $0.12 \pm 0.01$ & $0.13 \pm 0.01$ & $0.12 \pm 0.01$ & $0.12 \pm 0.01$ & $0.13 \pm 0.01$ & $0.12 \pm 0.01$ \\
\hline 2015 & $0.12 \pm 0.01$ & $0.12 \pm 0.01$ & $0.12 \pm 0.01$ & $0.11 \pm 0.01$ & $0.12 \pm 0.01$ & $0.12 \pm 0.01$ & $0.11 \pm 0.01$ \\
\hline 2016 & $0.13 \pm 0.01$ & $0.11 \pm 0.01$ & $0.12 \pm 0.01$ & $0.11 \pm 0.01$ & $0.13 \pm 0.01$ & $0.12 \pm 0.01$ & $0.11 \pm 0.01$ \\
\hline \multicolumn{8}{|c|}{ Rosa canina } \\
\hline 2014 & $0.11 \pm 0.01$ & $0.12 \pm 0.01$ & $0.13 \pm 0.01$ & $0.11 \pm 0.01$ & $0.13 \pm 0.01$ & $0.12 \pm 0.01$ & $0.12 \pm 0.01$ \\
\hline 2015 & $0.13 \pm 0.01$ & $0.12 \pm 0.01$ & $0.13 \pm 0.01$ & $0.13 \pm 0.01$ & $0.13 \pm 0.01$ & $0.12 \pm 0.01$ & $0.12 \pm 0.01$ \\
\hline 2016 & $0.12 \pm 0.01$ & $0.13 \pm 0.01$ & $0.12 \pm 0.01$ & $0.12 \pm 0.01$ & $0.12 \pm 0.01$ & $0.12 \pm 0.01$ & $0.13 \pm 0.01$ \\
\hline
\end{tabular}

amount of organic acids it was determined that the content of these substances in the raw material ranged from $3.38 \pm 0.23 \%$ (batch 6 , year 2015) to $5.07 \pm 0.31 \%$ (batch 5, year 2015) in the roots of Rosa majalis, and from $3.29 \pm 0.22 \%$ (batch 6 , year 2014) to $4.54 \pm 0.28 \%$ (batch 6, year 2015) in the roots of Rosa canina. It is distinctive of the roots of Rosa majalis that the amount of organic acids varied, e.g. by 1.2 times in samples of 2014, by 1.5 times in samples of 2015, and by 1.3 times in samples of 2016. However, this difference was 1.2 times for different batches of the roots of Rosa canina regardless of the year of collection.

The content of ascorbic acid in roots of Rosa majalis and Rosa canina fluctuated insignificantly (from $0.11 \pm 0.01 \%$ (7 samples) to $0.13 \pm 0.01 \%$ (12 samples)).

CONCLUSIONS

1. For the first time the quantitative content of the amount of organic acids and ascorbic acid in Rosa ma- jalis and Rosa canina roots collected during three years in seven different places has been determined.

2. It has been determined that the least content of the amount of organic acids in roots of Rosa majalis and Rosa canina fluctuated insignificantly; it was $3.38 \pm 0.23 \%$ and $3.29 \pm 0.22 \%$, respectively. The highest content of these substances in the roots of Rosa majalis was 1.1 times higher than in the roots of Rosa canina; it was $5.07 \pm 0.31 \%$ and $4.54 \pm 0.28 \%$, respectively.

3 . The further study of Rosa majalis and Rosa cani$n a$ roots is promising taking into account their possible areas of application (thus, the presence of not less than $3 \%$ of organic acids predetermines the antimicrobic activity of the raw material, while the presence of not less than $0.11 \%$ of ascorbic acid affects metabolic processes in the body).

Conflicts of Interest: authors have no conflict of interest to declare.

\section{REFERENCES}

1. Государственная фармакопея СССР. Вып. 2. Лекарственное растительное сырье / МЗ СССР. - 11-е изд. - М. : Медицина, 1989. - 400 с.

2. Державна фармакопея України : в 3 т. / Держ. п-во «Український науковий фармакопейний центр якості лікарських засобів». 2-е вид. - Х. : Держ. п-во «Український науковий фармакопейний центр якості лікарських засобів», 2014. - Т. 3. - 732 с.

3. 100 самых популярных лечебных растений / сост. : В. Рыжская. - Донецк : Мультипресс, 2010. - 287 с.

4. Assessment of anti-oxidant activity of plant extracts using microbial test systems / O. Oktyabrsky, G. Vysochina, N. Muzyka et al. // J. Appl. Microbiol. - 2009. - Vol. 106 (4). - P. 1175-1183.

5. The antiradical activity of plant extracts and healthful preventive combinations of these exrtacts with the phospholipid complex/V. S. Baranova, I. F. Rusina, D. A. Guseva et al. // Biomed. Khim. - 2012. - Vol. 58 (6). - P. 712-726.

6. Очередько, Л. В. Хромато-масс-спектрометричне визначення складу летких компонентів коренів шипшини коричної / Л. В. Очередько, Т. М. Крючкова, О. П. Хворост// Укр. мед. Альманах. - 2013. - Т. 15, № 5. - С. 52-54.

7. Очередько, Л. В. Хромато-масс-спектрометричне визначення складу органічних кислот коренів шипшини коричної / Л. В. Очередько, Т. М. Крючкова, О. П. Хворост // Укр. мед. Альманах. - 2013. - Т. 16, № 6. - С. 42-43.

8. Опрошанська, Т. В. Визначення кількісного вмісту кислоти аскорбінової та суми кислот органічних у сировині та густих екстрактах кореня і листя лопуха великого / Т. В. Опрошанська, О. П. Хворост // Проблеми екологічної та медичної генетики і клінічної імунології : зб. наукових праць. - 2011. - Вип. 6 (108). - С. 367-371.

9. Аминокислотный состав шиповника собачьего корней / В. Н. Киселёва, Н. В. Кобыльченко, Н. Н. Вдовенко-Мартынова, А. Н. Сепп // Разработка, исследование и маркетинг новой фармацевтической продукции : сб. науч. тр. - Пятигорск, 2009. - Вып. 64. - C. 61-62.

10. Вдовенко-Мартынова, Н. Н. Содержание биологически активных соединений в корнях шиповника (Rosa canina L.) флоры Cеверного Кавказа / Н. Н. Вдовенко-Мартынова, Н. В. Кобыльченко, Т. И. Блинова // Мед. вестник Северного Кавказа. - 2011. № 2. - C. 51-52. 


\section{REFERENCES}

1. Gosudarstvennaia farmakopeia SSSR. Vyp. 2. Lekarstvennoe rastitelnoe syre (11 ${ }^{\text {th }}$ ed.). (1989). Moscow : Meditcina, 400.

2. Derzhavna farmakopeia Ukrainy. (2014). (2nd ed.).(Vols. 1-3; Vol. 3). Kharkiv : Derzh. p-vo "Ukrainskyi naukovyi farmakopeinyi tsentr yakosti likarskykh zasobiv", 732.

3. Ryzhskaia, V. (2010). 100 samykh populiarnykh lechebnykh rasteniy. Donetck : Multipress, 287.

4. Oktyabrsky, O., Vysochina, G., Muzyka, N., Samoilova, Z., Kukushkina, T., Smirnova, G. (2009). Assessment of anti-oxidant activity of plant extracts usingmicrobial test systems. Journal of Applied Microbiology, 106 (4), 1175-1183. doi: 10.1111/j.1365-2672.2008.04083.x

5. Baranova, V. S., Rusina, I. F., Guseva, D. A., Prozorovskaya, N. N., Ipatova, O. M. (2012). The antiradical activity of plant extracts and healthful preventive combinations of these exrtacts with the phospholipid complex. Biomeditsinskaya Khimiya, 58 (6), $712-726$. doi: $10.18097 / \mathrm{pbmc} 20125806712$

6. Ocheredko, L. V., Kriuchkova, T. M., Khvorost, O. P. (2013). Ukrainskii medychnyi almanakh-Ukrainian medical almanac, 15 (5), $52-54$.

7. Ocheredko, L. V., Kriuchkova, T. M., Khvorost, O. P. (2013). Ukrainskiy medychnyi almanakh-Ukrainian medical almanac, 16 (6), $42-43$.

8. Oproshanska, T. V., Khvorost, O. P. (2011). Problemy ekologichnoi ta medychnoi genetyky i klinichnoi imunologii, 6 (108), $367-371$.

9. Kiseleva, V. N., Kobylchenko, N. V., Vdovenko-Martunova, N. N., Sepp A. N. (2009). Razrabotka, issledovanie i marketing novoi pharmatcevticheskoi prodyktcii, 64. Piatygorsk, 61-62.

10. Vdovenko-Martynova, N. N., Kobylchenko, N. V., Blinova, T. I. (2011). Meditcinskii vestnik Severnogo Kavkaza, $2,51-52$.

Information about authors:

Oproshanska T .V., candidate of Pharmacy (Ph.D.), associate professor of the Botany Department, National University of Pharmacy. E-mail: arctium55@ukr.net. ID orcid.org/0000-0002-3992-7183

Khvorost O. P., Doctor of Pharmacy (Dr. habil.), professor of the Chemistry of Natural Compounds Department, National University of Pharmacy.

E-mail: khvorost09101960@gmail.com. ID orcid.org/0000-0002-9534-1507

Ocheredko L. V., senior lecturer of the Physical Education and Health Department, National University of Pharmacy. E-mail: ocheredko_liliya@bk.ru.

ID orcid.org/0000-0002-9142-0208

Відомості про авторів:

Опрошанська Т. В., канд. фарм. наук, доцент кафедри ботаніки, Національний фармацевтичний університет. E-mail: arctium55@ukr.net.

ID orcid.org/0000-0002-3992-7183

Хворост О. П., д-р фарм. наук, професор кафедри хімії природних сполук, Національний фармацевтичний університет.

E-mail: khvorost09101960@gmail.com. ID orcid.org/0000-0002-9534-1507

Очередько Л. В., ст. викладач кафедри фізичного виховання та здоров’я, Національний фармацевтичний університет. E-mail: осhеredko_liliya@bk.ru. ID orcid.org/0000-0002-9142-0208

Информация об авторах:

Опрошанская Т. В., канд. фарм. наук, доцент кафедры ботаники, Национальный фармацевтический университет. E-mail: arctium55@ukr.net.

ID orcid.org/0000-0002-3992-7183

Хворост О. П., д-р фарм. наук, профессор кафедры химии природных соединений, Национальный фармацевтический университет.

E-mail: khvorost09101960@gmail.com. ID orcid.org/0000-0002-9534-1507

Очередько Л. В., ст. преподаватель кафедры физического воспитания и здоровья, Национальный фармацевтический университет.

E-mail: ocheredko_liliya@bk.ru. ID orcid.org/0000-0002-9142-0208 